\title{
PENGUATAN TEKNIK BUDIDAYA IKAN LELE (Clarias sp) SISTEM KOLAM TERPAL BERBASIS PENYULUHAN DAN PENDAMPINGAN DI DESA PATIHAN KECAMATAN WIDANG KABUPATEN TUBAN
}

\author{
Miftachul Munir ${ }^{1 *}$, Muhammad Yusuf ${ }^{1}$, Hendra Suwardana ${ }^{1}$ \\ Universitas PGRI Ronggolawe Tuban \\ ${ }^{*}$ Korespondensi: miftahulmunir886@gmail.com \\ Diterima 9 Mei 2020 / Disetujui 15 Juni 2020
}

\begin{abstract}
ABSTRAK
Budidaya Ikan Lele Clarios bisa dilaksanakan di area sempit dengan metode kolam terpal mampu menjawab penguasaan skill bagi pebudidaya pemula, menambah penghasilan, serta bisa memanfaatkan lahan pekarangan kosong untuk kegiatan ekonomis produktif. Terlebih bagi desa-desa yang secara alami berkelimpahan air, baik dari sungai maupun dari sumber masyarakatnya perlu didorong untuk menguasai teknis budidaya yang bisa menambah manfaat bagi kegiatan ekonomi rumah tangganya. Salah satu budidaya yang mempunyai keunggulan dan bernilai ekonomi adalah Budidaya Lele dengan metode kolam terpal. Agar hal ini bisa dilakukan oleh masyarakat, maka perlu adanya sosialisasi melaui pelatihan dengan pola yang tepat. Selain diberikan pemahaman materi dengan presentasi ceramah, percontohan merupakan langkah tepat untuk menyempurnakan penguasaan skill para pebudidaya pemula. Di samping, didampingi serta dalam evaluasi selama pelaksanaan percotohan itu didiskusikan sehingga baik secara pencerapan pemahaman maupun penguasaan skill akan lebih tersempurnakan. Kegiatan ini memberikan hasil yang baik. Secara kenyataan, hasil panenan dari 3000 benih yang ditabur di kolam terpel tersebut, angka kematiannya 24,4\%. FCR 1:1,09 dengan berat hasil panen $2.125 \mathrm{~kg}$ menghabiskan pakan $2.200 \mathrm{~kg}$. Dalam satu kilo ikan yang dipanen berisi 10,09 ikan Lele atau dikatan size 10,09 .
\end{abstract}

Kata Kunci: teknik budidaya Lele Clarias, ADG, FCR

\section{PENDAHULUAN}

Budidaya Lele Clarias skala rumah tangga perlu disosialisasikan agar masyarakat memperoleh manfaat tambahan penghasilan dengan memanfaatkan pekarangan di sekitar rumah. Terkait dengan hal tersebut, warga desa Patihan kecamatan Widang yang dikaruniai kemudahan mendapatkan air, karena di sekitar desa terdapat aliran air dari keberdaanBengawan Solo, belum secara optimal mampu memanfaatkan kondisi yang menguntungkan untuk berbudidaya ikanLele. Permasalahan yang ada pada warga desa Patihan adalah belummaksimal kemampuannyadalam teknis budidaya ikan, yang bisa 
menjadikan warga sebagai pelaku usaha budidaya ikan khususnya Lele metode kolam terpal yang bisa memanfaatkan pekarangan. Maka diperlukan penguatan teknis budidaya agar warga desa Patihan, kecamatan widang, Kabupaten Tuban, mendapatkan manfaat dari kondisi desa yang sangat cocok untuk berbudidaya ikan. Alternatif paling memungkinkan untuk memulai usaha adalah dengan budidaya Lele dengan metode kolam terpal. Selain mudah penanganannya, tidak membutuhkan lahan yang luas, keuntungannya bisa menambah pendapatan keluarga. Hal itulah yang melatarbelakangi diadakannya Penguatan Teknis Budidaya Lele Clarias Dengan Metode Kolam Terpal.

Penguatan ini diartikan sebagai pengamalan ilmu pengetahuan, teknologi dan seni (IPTEKS) yang dilakukan oleh perguruan tinggi secara melembagaagar bis memberikan manfaat kepada masyarakat, melalui metode penyuluhan langsung kepada masyarakat yang membutuhkannya. Dalam upaya mensukseskan pembangunan dan membangun manusia pembangunan. Selain itu, merupakan upaya pengentasan kemiskinan masyarakat desa, agar mempercepat akselerasi program pengentasan kemiskinan di pedesaan. Salah satu sektor yang bisa dijadikan percontohan bentuk adalah budidaya ikan lele, dengan media kolam terpal sebagai implementasi pengamalan ilmu pengetahuan, teknologi dan seni (IPTEKS). Tujuan kegiatan ini untuk memberi pelatihan budidaya pembesaran ikan lele sekaligus percontohan sebagai media pengabdian serta transfer teknologi .

\section{METODE KEGIATAN}

Metode kegiatan pengabdian masyarakat Penguatan Teknis Budidaya Ikan Lele (Clarias) BerbasisKolam Terpal ini berpolapenyuluhan dan pendampingan dengan metode kegiatan sebagai berikut :

a. Pendikan dan Peyuluhan sebagai bagian dari sosialisasi kepada kelompok pebudidaya Lele (Clarias) skala rumah tangga akan pentingnya penguasaan teknis budidaya yang baik dan benar.

b. Pendampingan, tahapan pendampingan merupakan tahap teramat penting, sbagai bagian dari mempraktekkan teknis budidaya Lele, mulai dari pembelajaran terkait kualitas air, manajemn pemberian pakan, penanggulangan hama dan penyakit pada budidaya Lele.

c. Penanganan panen dan pasca panen, merupakan bagian dari pendampingan dengan focus pada bagaimana memanen yang benar, jika pemnenan diperuntukkan memberi nilai tambah pada hasil panen Lele, maka kelompok pebbudidaya Lele diberikan penguatan penanganan pasca panen dengan pola seperti pengolahan.

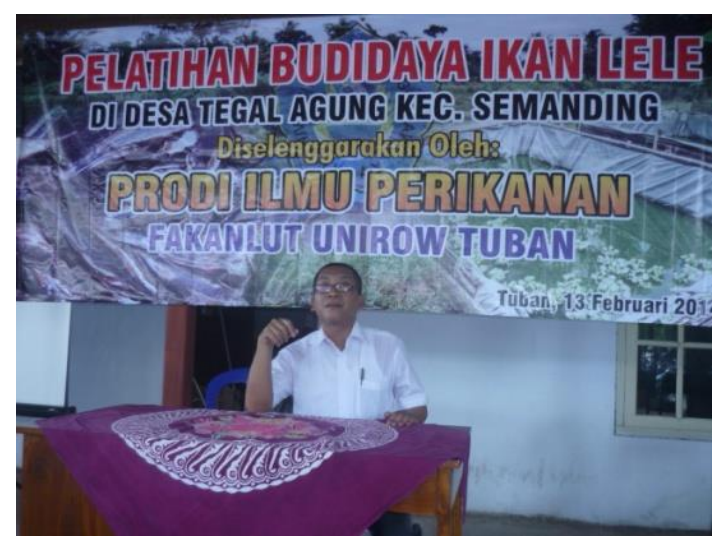

Gambar 1: Drs. Miftachul Munir, M.M. memberikan penyuluhan

Waktu Pelaksanaan:

1) 7 Januari 2020, Penyuluhan Teknis Budidaya.

2) 8 Januari 2020 Penyuluhan Manajemen Kualitas Air, Tebar benih yang benar dengan cara 
aklimatisasi,

Pengendalian manajemen kualitas air $\mathrm{pH}$, Suhu, Serta Disolved Oksigen/DO, serta menyuluhi tentang antisipasi kandungan cemaran)

3) Pendampingan selama 12 Minggu terhitung mulai tebar benih, untuk mendampingi perihal teknis budidaya dan penanganan panen dan pasca panen.

\section{HASIL PEMBAHASAN}

\section{Teknis Budidaya :}

\section{Persyaratan}

Persyaratan budidaya Lele dengan metode kolam terpal ini, tidak seperti pada area lahan (tanah) yang membutuhkan persyaratan tertentu sebelum memulai tabur benih Lele. Beberapa persyaratan pada kolam tanah, seperti pengeringan dasar kolam tanah harus memadai, $\mathrm{pH}$ harus diperhatikan dan salinitas air disikan ke dalam kolam lebih baik kisaran 0-3 promil merupakan persyaratan penting.

Ikan Lele dapat hidup dalam perairan agak tenang dan kedalamannya cukup, sekalipun kondisi airnya jelek, keruh, kotor dan miskin zat $\mathrm{O}_{2}$. Hal ini, lebih menguntungkan pebudidaya dengan metode kolam terpal. Adapun syaratsyarat budidaya metode kolam terpal di antaranya;

a. Kelayakan kepadatan pada Kolam Terpal, jumlah benih per seratus ekor membutuhkan lahan panjang $2 \mathrm{~m} \times$ lebar $1 \mathrm{~m} \times$ tingg $0,6 \mathrm{~m}$.

b. Mempunyai pH 6,5-9; kesadahan (derajat butiran kasar) maksimal 100 ppm dan optimal 50 ppm; turbidity (kekeruhan) bukan lumpur antara 30$60 \mathrm{~cm}$; kebutuhan $\mathrm{O}_{2}$ optimal pada range yang cukup lebar, dari 0,3 ppm untuk yang dewasa sampai jenuh untuk burayak; dan kandungan $\mathrm{CO}_{2}$ kurang dari $12,8 \mathrm{mg} / \mathrm{liter}$, amonium terikat 147,29-157,56 mg/liter.

c. Dekat dengan rumah pemeliharaannya, kedalaman air 30$60 \mathrm{~cm}$.

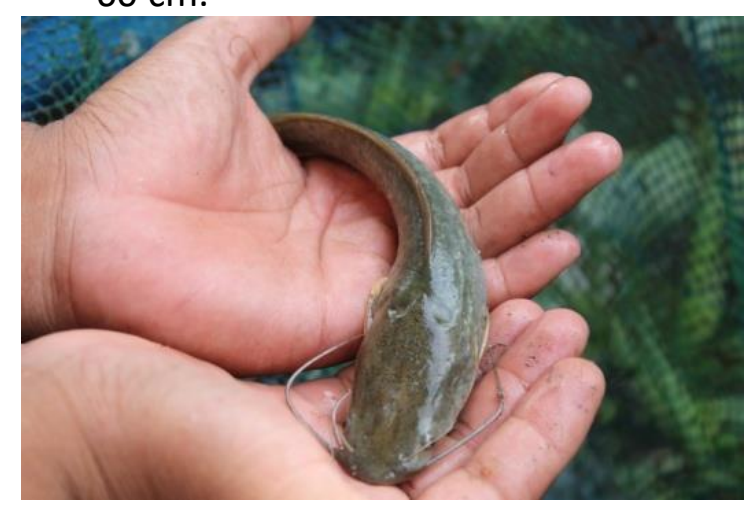

Gambar 2: Masa pertumbuhan lele

2. Pedoman Teknis Budidaya

a. Penyiapan Sarana dan Peralatan

Dalam pembuatan kolam pemeliharaan ikan lele metode Kolam Terpal, memudahkan pengontrolan dan pengawasan. Bentuk dan ukuran kolam pemeliharaan bervariasi, tergantung selera pemilik dan lokasinya. Pada minggu ke 1-6 air harus dalam keadaan jernih, kolam bebas dari pencemaran maupun fitoplankton. Lele pada usia 7-9 minggu kejernihan airnya harus dipertahankan. Pada minggu 10, air dalam batas-batas tertentu masih diperbolehkan. Kekeruhan menunjukkan kadar bahan padat yang melayang dalam air (plankton). Alat untuk mengukur kekeruhan air disebut secchi.

b. Penyiapan Tabur Benih

Menyiapkan Bibit Lele yang harus diperhatikan kesehatan benih, ukurannya sekitar panjang $5 \mathrm{~cm} \times$ lebar $3 \mathrm{~cm}$ dan beratnya relatif rata kisaran 3 gram. Kondisi airnya siap untuk awal hingga usia 4 mingga bisa dengan kedalaman air 0,3 $\mathrm{m}$, setelah itu perlahan disesuaikan dengan perkembangan Lele kedalaman air makin dalam hingga usia 10 minggu-12 minggu bisa mencapai kedalaman 0,6 m hingga di panen. 
c. Pemeliharaan dan Perawatan

Sebelum benih Lele di tabur ke Kolam Terpal, kolam diisi air dengan kedalaman 0,3 $\mathrm{m}$ dalam kondisi planton memadai agar benih mendapatkan pakan alami dari planton. Lele menurut teori hingga usia 4-5 minggu selain makanan alami berupa planton, disupplay juga makanan buatan (pellet) ukuran kecil (disesuaikan dengan ukuran dan berat Lele). Pakan pellet diberikan $2 x$ sehari dengan jumlah kisara $3 \%$ dri berat total Lele.

Pergantian air Kolam Terpal diperlukan untuk menjaga kualitas air yang akan berpengaruh terhadap kenyamanan Lele, serta untuk menghindari munculnya penyakit akibat kualitas air yang jelek. Pergantian air dilakukan dengan membuang (10-30)\% di dalam Kolam dan menambahkan dengan jumlah yang sama dengan air baru dengan kualitas yang baik, setiap seminggu sekali.

Melakukan penyortiran (greeding), dimulai ketika Lele berusia 4 minggu (1 bulan). Hal ini disebabkan pertumbuhan Lele setelah usia 4 minggu mengalami lonjakan amat pesat. Selain itu, pebyortiran dimaksudkan agar pertumbuhan Lele merata. Sedang, Lele yang lambat tumbuh dipindah ke Kolam Terpal lain agar tidak kalah bersaing dalam mendapatkan makanan, serta untuk menghindari kanibalisme (saling memangsa) sesuai sifat alami Lele.

\section{d. Pemberian Pakan}

Pemberian pakan disesuaikan dengan siklus dan sifat pertumbuhan Lele. Untuk usia 0-4 minggu diberikan makanan pellet dengan takaran $3 \%$ dari berat total keseluruhan lele, sehari diberikan 2 kali, dengan variasi pagi dan sore. Usia 4-12 minggu siklus pertumbuhan yang pesat pemberian pakan bisa (3-4) kali sehari, dengan jumlah disesuaikan kebutuhan kisaran (3-5)\% dari jumlah total Lele. Perbandingan pemberian pakan FCR (Feed
Convertion ratio) sebaiknya $1: 1$, artinya jumlah total pakan yang diberikan berbanding sama dengan berat total ikan yang dihasilkan.

\section{Penyuluhan, Aplikasi Dan Percontohan}

Penerapan metode dalam kegiatan ini, disarankan menggunakan metode kaji tindak, yaitu memberikan penyuluhan kepada kelompok budidaya lele yang ditetapkan di Desa Patihan kecamatan Widang-Tuban. Para pelaku pebudidaya diberikan materi Teknis Budidaya Lele Clarias dengan metode Kolam Kerpal serta diadakan pendampingan agar pebudidaya mampu menguasai teknis yang benar dalam budidaya Lele. Secara rinci tahapantahapan kegiatan tersebut meliputi:

1. Presentasi dan Komunikasi Ceramah Selain diberikan penjelasan dengan cara mempresentasikan materi tentang Teknik Budidaya Lele dengan Metode Kolam Terpal, juga diselingi dengan ceramah, yaitu serta berkomunikasi dalam penyampaian materi.

2. Diskusi

Para pebudidaya diajak berdiskusi selama diadakan pendampingan teknis selam diadakan kaji tindak pada budidaya percontohan, hal ini bermuatan evaluasi dan penyempurnaan pencerapan penguasaan teknis budidaya Lele.

3. Percontohan

Diberikan percontohan Berbudidaya Lele Dengan Metode Kolaqm Terpal melalui pemberian penyuluhan sarana prasarana budidaya, benih dan pakan Pellet agar materi teknis budidaya lele benar-benar dikuasai, yang akhirnya setiap pebudidaya telah mempunyai skill.

4. Pembahasan Hasil

Selama diadakan kegiatan penyuluhan dan pendampingan teknis budidaya Lele dengan metode kolam terpal di 
dapatkan hasil $2.125 \mathrm{~kg}$ lele, sedang total pakan $2200 \mathrm{~kg}$. Dari percontohan hasilnya terdeskripsi di bawah ini:

\begin{tabular}{|c|c|c|c|}
\hline $\begin{array}{c}\text { Minggu } \\
\mathrm{Ke}\end{array}$ & $\begin{array}{c}\text { Rata-rata } \\
\text { Berat/ekor } \\
\text { (gram) }\end{array}$ & $\begin{array}{l}\text { *ADG di } \\
\text { lapangan }\end{array}$ & $\begin{array}{c}\text { Rata-rata } \\
\text { pakan } \\
(\mathrm{kg} / \text { hari })\end{array}$ \\
\hline 1 & 3 & \multirow{4}{*}{$\begin{array}{l}\text { Minggu } \\
\text { ke 1-4 } \\
0,9 \text { Gram }\end{array}$} & \multirow{4}{*}{$\begin{array}{c}60 \mathrm{~kg}: 30 \mathrm{har} \\
\mathrm{i} \\
=2 \mathrm{~kg}\end{array}$} \\
\hline 2 & 6 & & \\
\hline 3 & 9,5 & & \\
\hline 4 & 11,1 & & \\
\hline 5 & 17 & \multirow{4}{*}{$\begin{array}{l}\text { Minggu } \\
\text { ke } 5-8 \\
1,1 \text { Gram }\end{array}$} & \multirow{4}{*}{$\begin{array}{c}73,3 \mathrm{~kg}: 30 \mathrm{~h} \\
\text { ari } \\
=2,4 \mathrm{~kg}\end{array}$} \\
\hline 6 & 23 & & \\
\hline 7 & 30 & & \\
\hline 8 & 42 & & \\
\hline 9 & 55 & \multirow{4}{*}{$\begin{array}{l}\text { Minggu } \\
\text { ke 9-12 } \\
\text { 1,2 Gram }\end{array}$} & \multirow{4}{*}{$\begin{array}{c}86,6 \mathrm{~kg}: 30 \mathrm{~h} \\
\text { ari } \\
=2,88 \mathrm{~kg}\end{array}$} \\
\hline 10 & 68,5 & & \\
\hline 11 & 79 & & \\
\hline 12 & 91 & & \\
\hline & TOTAL & $212,5 \mathrm{~kg}$ & $220,0 \mathrm{~kg}$ \\
\hline
\end{tabular}

*) ADG: Average Day Growth (Rata-rata Pertumbuhan Harian)

\section{Catatan:}

1. Benih Yang ditabur sebanyak 3.000 ekor. Total kematian selama 12 minggu Lele yang meninggal sebanyak 732 ekor atau $24,4 \%$.

2. FCR (Feed Convertion Ratio) 1:1,09. Dalam $1 \mathrm{~kg}$ Lele berisikan sekitar 10,09 ekor (atau size 10,09).

\section{Indikator Kegiatan}

1. Keluaran

Terlaksanana kegiatan pelatihan dan percontohan budidaya ikan Lele sistim kolam terpal.

3. Hasil

Meningkatnya kemampuan dan ketrampilan para anggota masyarakat pelaku budidaya dalam budidaya ikan lele.

4. Manfaat
Meningkatkan pendapatan para pelaku budidaya dan membuka lapangan kerja baru bagi masyarakat Desa Patihan,kec. Widang-Tuban.

5. Dampak

Meningkatnya kesejahteraan para pelaku budidaya dan masyarakat di sekitarnya

\section{KESIMPULAN DAN SARAN}

\section{Kesimpulan}

Kegiatan Pelatihan Teknis Budidaya Lele Clarios Dengan Metode Kolam Terpal telah berjalan sesuai rencana. Kesimpulan yang bisa diambil dari kegiatan inni, para pebudidaya dengan didampingi (dengan kehadiran pendampingan seminggu sekali, pada hariMinggu) telah mendapatkan penguasaan teknis budidaya yang bisa menjadikan dirinya sebagai pebudidaya yang baik. Sistem percontohan dan pendampingan dengan pemberian materi, berdiskusi dalam evaluasi secara langsung dengan para pebudidaya pemula, telah mampu memberikan bekal skill. Tentunya, dengan bekal skill tersebut, bisa memberikan manfaat bagi perkembangan kesejahteraan.

\section{Saran}

Kegiatan Penguatan Teknis Budidaya Ikan Lele berbasis Penyuluhan dan Pendampingan kurang berguna apabila dilakukan terputus hanya pada penyuluhan saja. Model penguatan berbasis penyuluhan, disertai percontohan, serta pendampingan secara nyata mampu memberikan kontribusi positif bagi masyarakat. Untuk itu, saran atau rekomendasi yang ingin disampaikan dari kegiatan ini adalah, dalam memberikan bekal skill terutama budidaya ikan, seharusnya tidak hanya diberikan tanpa ada contoh nyata secara praktek, didampingi serta diadakan evaluasi 
langsung dan secara bersama-sama antara pebudidaya.

\section{DAFTAR PUSTAKA}

Arifin, M.Z. 2006. Budidaya lele. Dohara prize. Semarang.

Djamiko, H., Rusdi, T. 2004. Lele. Budidaya, Hasil Olah dan Analisa Usaha. C.V. Simplex. Jakarta.

Djatmika, D.H., Farlina, Sugiharti, E. 2003. Usaha Budidaya Ikan Lele. C.V. Simplex. Jakarta.

Najiyati, S. 2007. Memelihara Lele Dumbo di Kolam Taman. Penerbit Swadaya. Jakarta.

Simanjutak, R.H. 2009. Pembudidayaan Ikan Lele Lokal dan Dumbo. Bhratara. Jakarta.

Soetomo, M.H.A. 2007. Teknik Budidaya Ikan Lele Dumbo. Sinar Baru. Bandung.

Susanto, H. 2010. Budidaya ikan di Pekarangan. Penebar Swadaya. Jakarta. 